\title{
Religious Education as a Key for Restructuring for National Development in Nigeria
}

\author{
John Friday Mordi \& Ejime Daniel Banwune \\ http://dx.doi./org/10.4314/ujah.v21i3.8
}

\begin{abstract}
The question of "restructuring" for national development has taken the central stage in the political, social and economic life of the Nigeria nation. This question hangs on the understanding that Nigeria as a nation is bedevilled with ethnic divisions occasioned by distrust, suspicion and perceived marginalization. To this end, arguments abound that the entity called Nigeria is not yet a nation but a creation of the erstwhile colonial masters, to favour a particular ethnic nationality. Restructuring therefore is perceived as the only veritable solution to the problem of ethnic divisions in Nigeria, as this would enhance sustainable national development. This research submits that religious education is a fundamental key for restructuring for the enhancement of national development that is sustainable and enduring. It further proposes true Federalism as a system of government that would work pari-pasu with religion to achieve this goal of restructuring for sustainable development.
\end{abstract}

\section{Introduction}

The Nigerian nation is witnessing renewed agitations for political, social and economic restructuring. These agitations are reinforced by individuals, geo-political groups, ethno-cultural groups and other groups of interest. The call for restructuring is best understand within the context of sustainable national development and reinforcement of national unity and integration. This means that restructuring should be geared towards the reintegration of all ethnic nationalities and ensure 
a sense of belonging to the various ethno-geo-political entities and segments of the Nigerian pluralistic society.

The ethnic superiority of a particular ethno - cultural segment and a perceived marginalization of the majority of the other ethnogeo-political extractions seem to be the bone of contention that has occasioned the agitations for restructuring. This understanding suggests that the Nigerian nation is anchored on structural injustice which has snow-balled into economic, political and social inequalities of the ethnic groups that make up the Nigeria nation. In some quarters, cries of marginalization and secessionist tendencies have taken the centre stage both covertly and overtly. The proscription of some agitators and branding them terrorists in a country where some herdsmen go on rampage with their horrendous massacres in communities across the country, armed with all forms of dangerous weapons, and walk freely everywhere, speak volume, about the intentions of the leadership of the Nigerian nation. The feeling of hurt and distrust among ethnic nationalities which are consequent on the failed leadership system has hampered the growth, progress and sustainable development of our nation.

This study argued that religion is a vital tool for restructuring and enhancing national development. Religion is a binding force which is cohesive in establishing the fundamental goals of man and helps him to live in peace both with God and his fellow human beings. In its belief that all men, ethnic nationalities and human institutions have a common origin and final end, religion teaches and encourages peaceful co-existence and common development for all. The feeling of supremacy by a group over other groups is condemnable by all religions. Favouritism of a group over others is inimical to religious tenets. Therefore, religious education helps to correct the error of a group lording it over other groups; thereby giving way for restructuring for the sake of justice and equity. 


\section{What is Restructuring}

This term has been variously defined by many people depending on the perspective from which they looked at it. Former military president of Nigeria, Ibrahim Babangida, as quoted by Sheshi and Salahu et al (2019), defined restructuring as "a devolution of powers to the extent that more responsibilities are given to states, while federal government is vested with the responsibility to oversee our foreign policy, defence and economy. Accordingly, Atiku Abubakar is quoted by Sheshi et al (2019), as conceiving restructuring as devolution of more powers from the Federal Government and deemphasizing federal allocations as source of sustenance of states.

Adeogun (2017), conceived restructuring as the restoration of Federalism in Nigeria as it stands entrenched in the 1963 Republican constitution, or as a federalism with independent self-sustaining federal units able to develop infrastructure, critical amenities, undertake other projects, education and health without a central body interfering. For Bello (2017), restructuring is the process of increasing or decreasing the number of component parts that make up a system and re-defining the inter-relationship between them to ensure efficiency of the entire system. Agidigbi (2019), posited that restructuring as it concerns Nigeria is the re-constitution of everything that make up the Nigeria policy. This means that the states and regions should be allowed to exist on their own, manage their resources and undertake their developmental projects without interference from the centre. Restructuring, understood from this perspective, will put the protracted ethnic tension and distrust to rest and enhance sustainable development.

Obiora (2018), sees restructuring as a change of the existing system in ways they used to be, a change in existing status quo in order to make it more functional. This view implies that to restructure is to have a purpose-driven activity that depends on replacement of an 
existing nature of a system with a new one, suitable to achieve the purpose of the system.

From the above definitions, it is evidently clear and endorsed by this study that restructuring is a significant change, alteration, reconstitution, re-organization, reformation and a rearrangement of the existing structure, status quo and politico-economic arrangement of Nigeria in a more revolutionary or evolutionary manner (Idemba, 2018), to allow the different states, ethnic nationalities and regions to control their resources and execute their developmental projects without the interference of the federal government. It is the case that all they need to do is to contribute their quota or pay their dues to the federal government for the maintenance of the centre, instead of using their resources to develop other states or regions and leaving their own undeveloped.

\section{Federalism}

This is a system of government in which constitutional powers are shared in one national Political entity between a central government and sub-national units, such as regions, states or zones in such a way that the one tier of government is not superior to the other (Moghalu, 2018).

Ramphel (1979) defined federalism as a process of unifying power within the cluster of states and decentralizing power within the unified system. True federalism implies that internal sovereignty is preserved and external sovereignty is limited. It encourages the ethnonational components that make up the confederation and emphasizes decentralization and devolution of powers. Federalism as a system of government advocates that sovereignty and political power are conglomerated within a single nation, irrespective of the territorial units, geo-political zones or ethic-nationalities, and are distributed between national and unit governments and at the same time maintaining substantially, their autonomy and independence. It means 
that the regional, state or geo-political governments have broad local responsibilities and have the autonomy to discharge their duties to their people in concert with the whole people of the Federation.

Ikemba (2018), averred that federalism is in congruence with a republic of republics, because it emphasizes partnership and cooperation for the welfare of all, and at the same time encouraging healthy competitive strives to foster efficiency and sustainable development.

\section{Religious Education}

This is a reference to the moral guidance, instruction and education provided by the different religions, whose contents include ethos, morality, tabors, beliefs and tenets (Mordi and Banwune, 2015). Religious education is understood as the foundation of social and moral progress in any society. Since religious education is based on religious beliefs, tenets and practices, it is pertinent to note that the power of such education rests on religion itself. Religion, therefore, is the relationship between man and the divine. In its correlation, religion has a bi-functional tendency - it unites man with the divine in its vertical comprehension and unites man with man in its horizontal functionality. Vertically, it establishes that God is man's origin and end; all men are therefore of the same origin and will one day be so united. Horizontally, religion establishes love and brotherhood between humans, knowing fully well that all men bear the image of God in them, have the same destiny on earth and the same goal to pursue. Ojo (2014), maintained that religious education is the instrument of moral and social change and reconstruction hence growth and development result in the conception that religious education is a constant reorganization or reconstruction of daily experiences either as individuals or as a people. Religious education conceived thus, has all the time an immediate end, it reaches that end which is the direct transformation of the quality of experiences to 
better ones. It is a panacea to all that can bring about change and development in any society; hence it is an instrument that can foster restructuring for national development, its dysfunctionality notwithstanding.

\section{The Need for Restructuring}

It is evident that there is need to restructure Nigeria. The agitations to this effect are loud and clear. This call has been on for quite a long time though successive governments in Nigeria have not done much to address it. The best that has been done has been the organization of the 2005 National Policy Reform Conference (NPRC) and the 2014 National conference, whose results are yet to impact on the nation. Why the nonchalant attitude to the call for restructuring in Nigeria? Bello (2017), advanced three reasons;

i. Some people believe that such exercise may not succeed in moving the nation forward and may be counterproductive'

ii. Those who called for restructuring in the past failed to explain what they meant and did not define the scope, modalities or timing of such an exercise;

iii. The calls for restructuring have been from individuals and minority groups.

The agitation for restructuring today however, has gone beyond the bounds of individuals and minority groups. It is a national issue that must not be ignored. This is because the failure to address this in the past have caused some hurt feeling, suspicions and distrust which invariably have hampered the pursuance of peace, unity, and nation building. If Nigeria must move forward as a nation, restructuring is inevitable.

\section{Why We Must Restructure Nigeria}

In his Keynote address to the $6^{\text {th }}$ Annual conference of the Nigeria political Science Association, Southeast, Moghalu (2018), identified 
four reasons why Nigeria must restructure. He averred that restructuring is very essential to the nation because it will reposition our democracy for better results. For him, the periodic elections cannot do as much as restructuring can do. Restructuring helps to revitalize the periodic elections thereby positioning them for better governance. It will also according to him, reduce the cost of governance at both the Federal and regional levels.

Nigeria as an entity is a creation of the colonial masters, a lumping together of many ethnic nationalities who did not come together to negotiate their future. These ethnic nationalities had no terms of agreement as one people hence the Nigerian nation could be referred to as a nation in the making, waiting to be born. Given the diversity inherent in the ethnic components of Nigeria, the best form of government that could guarantee national unity and social cohesion and at the same time foster sustainable development is true federalism. This form of government will ensure the total overhauling of the 1999 constitution currently in use for the achievement of national unity. True federalism will encourage the development of all the component parts; regions and zones of the federal state at their own pace and instance. Though we are said to be practicing a federal system of government, what we have on ground is nothing but a unitary system, where the centre holds power and dictates for the states and regions (Omordia, 2018). Restructuring is therefore needed in order to set things right politically.

From the above analysis, it is evident that there is no justice and equity in the Nigeria polity. Restructuring is needed to ensure this. The present Nigeria constitutional and political structure concentrate power in Abuja and favour some parts of the country and according to Nmorka (2019), disenfranchise others; from where the country's natural resources flow. This is so because they are denied the power to control their resources and are made to depend on what 
Abuja gives to them as allocation. This surely is political aberration and federal anomaly.

The main essence of a federal system of government is that it is formed by its constituent units and an appropriate balance of power between the constituent units and the centre is maintained. This unfortunately has been perverted in Nigeria hence the injustice and disunity in the polity. Restructuring is needed in Nigeria to correct these political errors and make the nation functional again.

The Nigerian nation has been destabilized by the current conditions the failed system has caused. According to Budaya, (2018), when we fail to appreciate the fact that the Nigerian problem is not the "process" but the "structure", conflict, animosity and distrust will continue to thrive in various quarters. For instance, the conflicts, instability, security challenges and all the other socio-ethnic crisis which have defiled the apprehension of the overstretched and over-centralized police force, and the "siege-style security governance in which our armed forces are constantly deployed to check-mate internal uprisings and ensure lasting security will not work, until we address the structure of Nigeria (Oloromo, 2018).

Restructuring is imperatively necessary in Nigeria in order to uphold the rights of the people. The constitution in operation today is not people oriented. We need a people's constitution, a democratic constitution based on the life, experiences and needs of the people, a constitution which will be portent enough to address the daily issues that bedevil the people. The constitution in use today was made by the military juntas and this has failed to guide our democratic practice as the government of the people, for the people and by the people.

To restructure is to follow the path of economic and social transformation. It is through transformation, reformation and restructuring that the economy of any nation is revived and receives its boost to impact on the people. The geo-political zones and regions of the federation should be allowed to devise ways of revitalizing 
their resources for their economic transformation. If they harness the sources of their resources, development would be sustained. Again, in the manufacturing sector, the regional governments can engage in inter and intra-regional trades as well as international trade. Here, we make it clear that the restructuring that is based on the 36 state structure may not be very effective because some states are not natural resources viable. Restructuring should be regionally or geopolitically based for national development.

\section{Religious Education and the Project of Restructuring}

Religious education is the catechesis that teaches morality, equity, fair play and justice. The various religions advocate the catechetical training of people in their mystagogic orientations. Elue, (2012) observed that religious education has a very strong social dimension which makes it to be experimented. In its social role, religious education promotes equity and the reorganization and reconstruction of the human society for the common good. This makes it a social ideal. Ebeburu (2013) noted that an ideal society where democracy is practiced could be the end result of a good religious education. This is because it teaches individuals and groups to develop interests in social, economic and political relationships, and form the habit of mind, which secure social changes without introducing disorder.

Accordingly, a good religious education or catechesis removes barriers such as class, colour or politics of discriminations and teaches that meanings, values, interests and goals should be upheld in good faith.

In line with the above analysis, it is deducible that religious education fosters the interest to promote democracy and sustain same. This is the full meaning of restructuring. The idea of restructuring implies making our country work, in order to enhance progress and development. Religion imposes on its adherents the task of helping to build a nation that is both progressive and development oriented. In 
its teaching on civic responsibility, religion makes it imperative for its practitioners to be at the lead in the struggle for development. Thus restructuring is a struggle, a fight and a project that is supported and enhanced by religion.

Religious education is a key to restructuring in Nigeria because it can help the individual to realize his aspirations and prepare him to perform his role in the society. If the project of restructuring is the aspiration of the Nigerian people and if they accept their religious and moral education tenets, it will surely provide them with the will power, the boldness and the determination to engage in the project.

To restructure includes to change our value-orientation and develop a nationalistic attitude that is both pragmatic and experimental. Religious education truly provides that and trains the human person to embrace a positive change in orientation and value for the common good. Akenzuwa (2016), submitted that religion and its catechetical training have the capacity to prepare the human person (who is a human capital) to effect positive society changes whose end-result would be the transformation, reorganization and restructuring of the social order for better developmental strives. This is corroborated by Omeife (2017), who said that religion is the agent of reconstruction and restructuring of the society. He argued that in the $12^{\text {th }}$ century, the church took over the decaying education in Europe and restructured the society through it. Modern Western education is indebted to this restructuring through education by the church.

Functionally, religion serves as an instrument of social control. This is achieved through the sermons and homilies of welltrained clergymen who admonish the faithful to live well and help to build the society in which they live. The punishment of doing the contrary is always believed to be eternal suffering in hell. It is also achievable through the use of socio-religious sanctions and ostracism. 
Restructuring as a means of building and repositioning the social order for better development can be encouraged through the doctrine of civic responsibility of the various religious groups.

Restructuring, basically, is a project that involves a reconveyance of the various ethnic nationalities and regions to address the problem of the country and to project a way forward. In its content, restructuring will include the following;

a. A review of resource control,

b. The relationship between the federal government and the regional governments;

c. The contribution of the regional governments to the government at the centre;

d. The representation at the federal level by the regional governments;

e. Regional policing in relation to federal policing; the relationship between the regions' trade and development programmes, initiatives and cooperation between them for the enhancement of national development.

Religion can help to actualize all these if it is understood as the relationship between man and God, on the one hand; and man and his fellow man, on the other. Since it teaches the common origin and end of all humans, religion will foster love and brotherhood which will be the driving force of the achievement of the project of restructuring in Nigeria.

\section{Conclusion}

This study has critically and carefully analyzed the concepts of restructuring, federalism, and religious education. In a very succinct manner, the study established that there is need to restructure the Nigerian polity, demonstrating that the problem of Nigeria is not the process but the structure. It concluded that religious education being a catechesis that is based on social cohesion, has all it takes to act as a 
key for restructuring Nigeria for sustainable national development. The study concluded that since religion and religious education are agents of social development and control, they have the key to the success of the project of restructuring the Nigerian polity.

\section{Recommendations}

a. The project of restructuring is a noble one and must be pursued with all zeal and vigor.

b. Restructuring should embrace all aspects of the Nigeria polity.

c. The dysfunctional aspects of religion should be de-emphasized.

d. The restructuring project should be clearly explained to all geopolitical zones and regions of the country and its benefits should be emphasized.

e. Religion (African Traditional Religion, Christianity and Islam) should be understood as a way of relating with God and enhancing a better relationship between man and his fellow man, hence its relevance to the existential situations of the citizenry should be upheld.

f. Government should encourage religious bodies and traditions to perform their functional roles in the society as their divine mandate.

g. Government and all stakeholders should encourage religion to contribute its quota to the restructuring programme of the Nigerian nation.

John Friday Mordi, PhD

Department of Christian Religious Studies

College of Education, Agbor

rev.mordijohn@yahoo.com

$\&$

Ejime Daniel Banwune

Department of Christian Religious Studies

College of Education, Agbor

banwuneejime@yahoo.com 


\section{References}

Adeogun, A.A. (2017) Nigeria Unity depends on restructuring. Interview by Leadership Newspaper. June 12, 2017.

Agidigbi, S.O (2019) Restructuring Nigeria: Panacea to Sustainable Development. Benin City. Liberty Publications, PP. 28-29.

Akenzuwa O.B., (2016). Religion and its Power of Catechesis: A pamphlet on the catechetical mission of Religion. Agbor: Ledi Printing house. P. 12

Bello, S.A. (2017) Restructuring Nigeria: A critical analysis. This Day New paper, June, 11, 2017.

Budaya A.C. (2018) Process and Structure, Which One Is Our Problem? Benin City: Budaya Prints. P. 63.

Ebeburu, A.O. (2013), Religion and its function in the Society. Benin City: Ehime Printing House. P. 45.

Elue, M.O (2012) "The Need for Religious and Moral Education in Nigerian Schools". A paper presented to the Issele-Uku Diocesan Education commission on the flag-off of the church's involvement in education industry in Delta State

Idemba, O. (2019) The Challenges of Political Restructuring in Nigeria and The Future of Federalism. Awka: Anolion publishing house. P. 35

Ikemba, P.O. (2018), Federalism and the Politics of the Nigerian Nation: An Examination. Nimo: Judex publishers. PP 34-35

Moghalu, L.C. (2018). "How to Restructure Nigeria. Why, What, How and When". A keynote address presented at the $6^{\text {th }}$ Annual conference of the Nigerian Political Science Association, South East Nigeria.

Mordi, J.F., Banwune, E.D. (2015) The Role of Religious Education in fostering Democracy in Nigeria, in Konyeme J.E. Umeoduagu, J.N., Uche, J.I Ukadike, J.O. Chukwuma, R.A. Ohen, C.C., Umeri, C., (eds), Journal of studies in Education . 
Vol. 2. No. 2. Benin City: Ayo-mat prints and Published, P. 168.

Obiora T.I. (2019), Restructuring Ethnic Politics in Nigeria Ibadan: Heinemann Educational Books. Pp 21-22

Ojo, A.O (2014) The Social Role of Religion: A Functional perspective. Ugo. Osaze Printing and Publishing company P. 34.

Oloromo S.A. (2018), The State of the Nigeria Police and Armed Forces. Ugo: Osaze Printing and Publishing company. P. 10

Omeife, S.D. (2017). The Social Role of Religion. Ubulu-Uku: Jide Prints. P. 28.

Omordia O.A. (2018) "The Meaning of The Project of Restructuring". A lecture delivered at the Political Rally of young Edo Politicians, held at the Oba Akezua Hall.

Ramphal, S.S. (1979). Keynote address in Akinyemi, A.B. Cole, PD and Ofonogoro, W. (eds) Preface to Reading on Federalism in Nigeria. Lagos: Nigeria institute of International Affairs, P. xiv

Sheshi; T.S. Salahu, M. Ilyasu Y.A. (2019): The Politics of Restructuring and the Nigeria Unity: The Role of the Leadership in, International Journal of arts and Humanities (IJAH) retrieved 13-10-2019 http:/dx.doi.org.10.43/ijahv8 12.4. 